\title{
The flight of the shrike. The ornithological representation in the Baptism of Christ (1470-1475 c.) by Andrea del Verrocchio and Leonardo da Vinci
}

\author{
Marco Masseti
}

\begin{abstract}
The artists of the Italian Renaissance were keen observers of nature. Their works are often enriched with realistic details that inform us about the high degree of their scientific knowledge. In the particular case of the Baptism of Christ (1470-1475 c.) by Andrea del Verrocchio and Leonardo da Vinci, the careful depiction of certain bird species, including a red-backed shrike and a redstart, reveals precise meanings closely related to Christological symbolism.
\end{abstract}

Key words: Andrea del Verrocchio, Leonardo da Vinci, red-backed shrike, redstart.

Riassunto - Il volo dell'averla. La raffigurazione ornitologica nel Battesimo di Cristo (1470-1475 c.) di Andrea del Verrocchio e Leonardo da Vinci.

Gli artisti del Rinascimento italiano erano acuti osservatori della natura. Le loro opere sono spesso arricchite da dettagli realistici che ci informano sull'alto livello delle loro conoscenze scientifiche. Nel caso particolare del Battesimo di Cristo (1470-1475 c.) di Andrea del Verrocchio e Leonardo da Vinci, l'attenta rappresentazione di alcune specie di uccelli, tra cui un'averla piccola e un codirosso, rivela precisi significati strettamente legati al simbolismo cristologico.

Parole chiave: Andrea del Verrocchio, averla piccola, codirosso, Leonardo da Vinci.

\section{INTRODUCTION}

The attribution of the correct taxonomic position to a botanical or zoological species depicted in a painting, a miniature or any other artistic representation is strictly dependent on the degree of adherence to reality of the artist's skills (Masseti, 2001 and in press). The closer the representation is to reality, the easier it is for the specialist to recognise the species it belongs to. Identifying the correct species also means understanding the cultural significance of the biological element depicted, its symbolic function within the context in which it was artistically

Dipartimento di Biologia dell’Università di Firenze, Via del Proconsolo 12, 50122 Firenze, Italia.

E-mail: marcomasseti55@gmail.com

\section{(C) 2021 Marco Masseti}

Received for publication: 26 April 2021

Accepted for publication: 8 September 2021

Online publication: 29 October 2021 evoked. On the contrary, incorrect taxonomic attribution also means not understanding the cultural significance it bears.

Let us take for example the ornithological representations in the impressive Baptism of Christ (Fig. 1), an oil painting by the Florentine painter Andrea del Verrocchio, dated between 1470 and 1471. As is well known, this is one of the earliest surviving works in which the contribution of the young Leonardo da Vinci can be documented. Originally conceived for the church of the Vallombrosian monastery of San Salvi in Florence, the painting is now on display in the Uffizi Gallery. Along the shores of the river Jordan, in Palestine, Jesus receives the sacrament of baptism from Saint John. The Baptist holds a slender cross and a scroll inscribed with

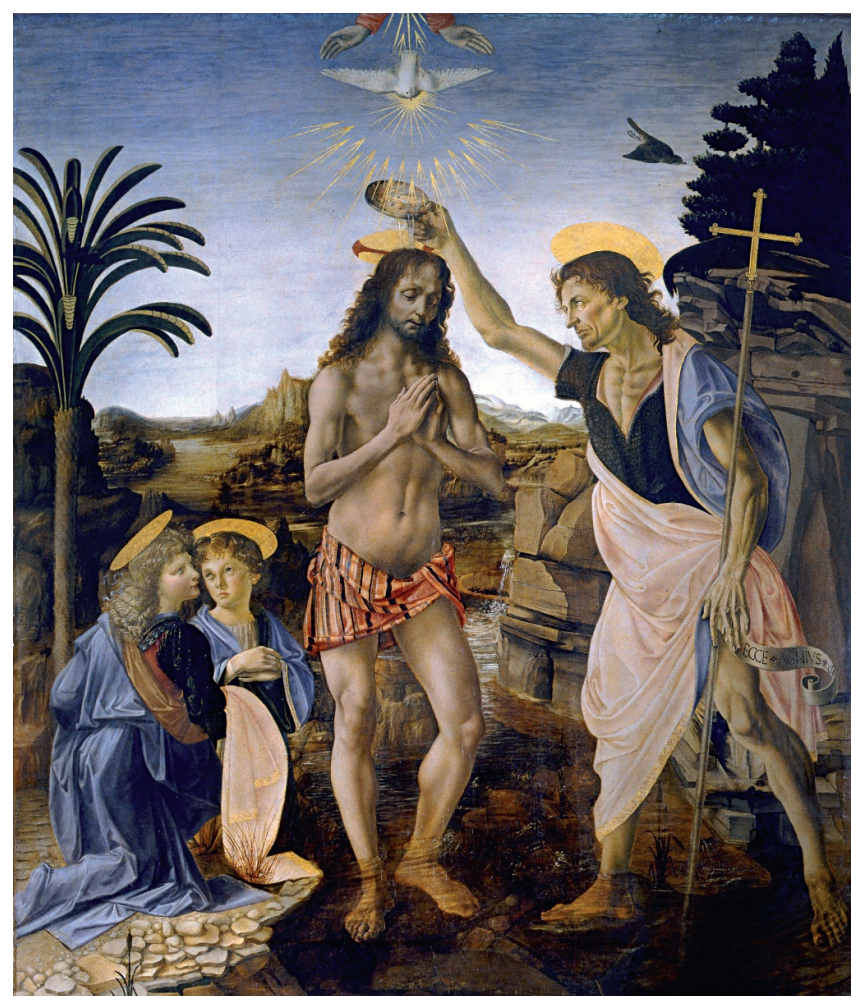

Fig. 1 - The Baptism of Christ (1470-1471), oil painting by Andrea del Verrocchio. / Battesimo di Cristo (1470-1471), olio su tavola di Andrea del Verrocchio. (Courtesy Gallerie degli Uffizi, Firenze). 
the announcement of the coming of the salvator mundi: Ecce Agnus Dei ... (Gospel of John 1, 29). Two kneeling angels witness the event, one of whom is holding Jesus' robe.

\section{A WHITE DOVE AND A SWAN}

In the sky, above the head of Christ, hovers the Holy Spirit traditionally depicted in the form of a white dove, a depigmented domestic variety of the wild pigeon, Columba livia Gmelin 1789. At all times, human cultures have attributed an important role to this bird in economic traditions as well as cultic liturgies.

Immobile in the air, with its wings stretched out and the tail feathers open like a fan, eternal symbol of the mystery of the divine Trinity, the Holy Spirit, the third element of dogmatic synthesis with the Father and the Son, hieratically illuminates the sacredness of the Catholic rite. For a long time religious iconography has attributed to this mystery the distinctive morphology of the white dove, symbol of purity and vivifying peace (Masseti, 1979). The immaculate colour of the dove's plumage openly alludes to the purity and the sanctity of the Holy Spirit (Levi D'Ancona, 2001), being at the same time the expression of a genetic mutation whose luxuriance has been encouraged by domestication. The pigeon is a rupestrian species bred by humans since very ancient times. It has adapted very easily to living on the stone facades of the buildings of villages and towns, also taking the name of domestic or feral pigeon. It appears in interesting concentrations in anthropogenic sites starting from the Natufian cultural horizons of the Levant, about 10,500 - 8,200 B.C. (Masseti, 2002). These findings have suggested the possibility of the establishment of a sort of commensalism between pigeons and human beings, before it was fully subjected to domestication, when the development of the first forms of agriculture made large quantities of trophic resources available to this predominantly granivorous species (Tchernov, 1984). Today the species has a Palaearctic, Afrotropical and Oriental natural distribution, and in its domestic breeds, it has spread all over the world.

In Verrocchio's Battesimo di Cristo, the evanescent presence of another bird is barely noticeable just below Christ's right elbow (cf. Natali, 2002). It is a minuscule swan (genus Cygnus Garsault, 1764), floating on the motionless waters of the river artistically evoked in the background of the painting. It is not possible to suggest a taxonomic identification for it, given the approximation and the dimension of the painted detail. No species of swan was probably native to peninsular Italy at the time, but these birds were kept in a semi-domestic status both as an adornment to noble dwellings, and as a source of food (cf. Yalden \& Albarella, 2009). The image of the swan has been traditionally connected to the immaculate whiteness of the Virgin Mary, as well as a symbol of her purification (Levi D'Ancona, 2001). Sometimes, the candid bird may also be one of the symbols of the birth of St John the Baptist (cf. Picinelli, 1681), a meaning that may have been attributed to it by its inclusion in the background of Verrocchio's painting.

\section{A FLYING SHRIKE}

Just talking about the latter artistic work, Natali (1998a, 1998b) observes that: "[...] it may be difficult to argue that fleeing birds of prey are frequently depicted in the Baptisms of Christ, and in full view, as the one flying over John's head in the Florentine panel", or another portrayed among the palm fronds. He refers evidently to the image of a bird caught in flight in the right-hand portion of the painting, above the Baptist's head as it heads towards a nearby group of trees. Natali (1998a, 1998b, 2002 ) identifies this animal as a raptor, a bird of prey (Fig. 2). However, a more careful observation by Antonioli Ferranti (2012) has correctly attributed the morphology of the ornithological image to a red-backed shrike, Lanius collurio L. 1758, and in particular to an adult female of this species (Fig. 3). This is a small breeding migratory bird, whose maximum length does not exceed 17-18 cm on average (Peterson et al., 1961; Heinzel et al., 1998). The species is found breeding south from the northeastern corner of the Iberian Peninsula across southern Italy to the Levant (Harris \& Franklin, 2000; Brichetti \& Fracasso, 2011; BirdLife International, 2021). In winter, it moves to tropical Africa and as far south as the Cape Province.

According to Antonioli Ferranti (2012), the shrike "[...] was considered in the various moralising bestiaries, which were very popular at the time, as a decidedly negative symbol". The same author is of the opinion that the red-backed shrike was called falconcello in the $15^{\text {th }}$ century, citing a sonnet from the $13^{\text {th }}$ century Bestiario moralizzato, also known as Bestiario di Gubbio, which describes the predatory action of certain unidentified falconcelli (= "little falcons") upon doves. According to Antonioli Ferranti (2012), the sonnet constitutes a variation relative to the doves of the Physiologus, a Greek didactic Christian text compiled in Alexandria, and traditionally dated to the $2^{\text {nd }}$ century AD (cf. Zambon, 1975). The same author, however, does not explain where did he get the association between the term falconcello and shrikes, nor gives any information about his sources. In this regard, it can also be noted that Caterini \& Ugolini (1938), in their 1938 Dizionario dialettale italiano degli uccelli d'Italia, report the entry falconcello as a dialectal synonym for the woodchat shrike Lanius senator L. 1758. The latter is a member of the taxonomic family Laniidae as well, larger than the red-backed shrike, but also widespread in the western Palaearctic region (Heinzel et al., 1998).

To be honest, however, I do not see any explicit reference to a representative of the genus Lanius L. 1758, in this sonnet. Rather, it seems to me that it speaks of other birds of prey, much larger than a shrike and able to prey on animals the size of doves. In fact, I would like to note that the red-backed shrike is much less than 20 $\mathrm{cm}$ long, whereas the average length of a pigeon ranges from 31 to $34 \mathrm{~cm}$. It seems much more likely, therefore, that the sonnet De Li Falconcelli, quoted by Antonioli Ferranti (2012), could refer to real falcons although not too large, but considerably larger than a shrike, and undoubtedly capable of preying on birds such as pigeons. After all, the just mentioned literary composition tells us that: "Nello paese sono falconcelli,/che le colombe amano de pigliare" (= "In the country are little falcons,/ 


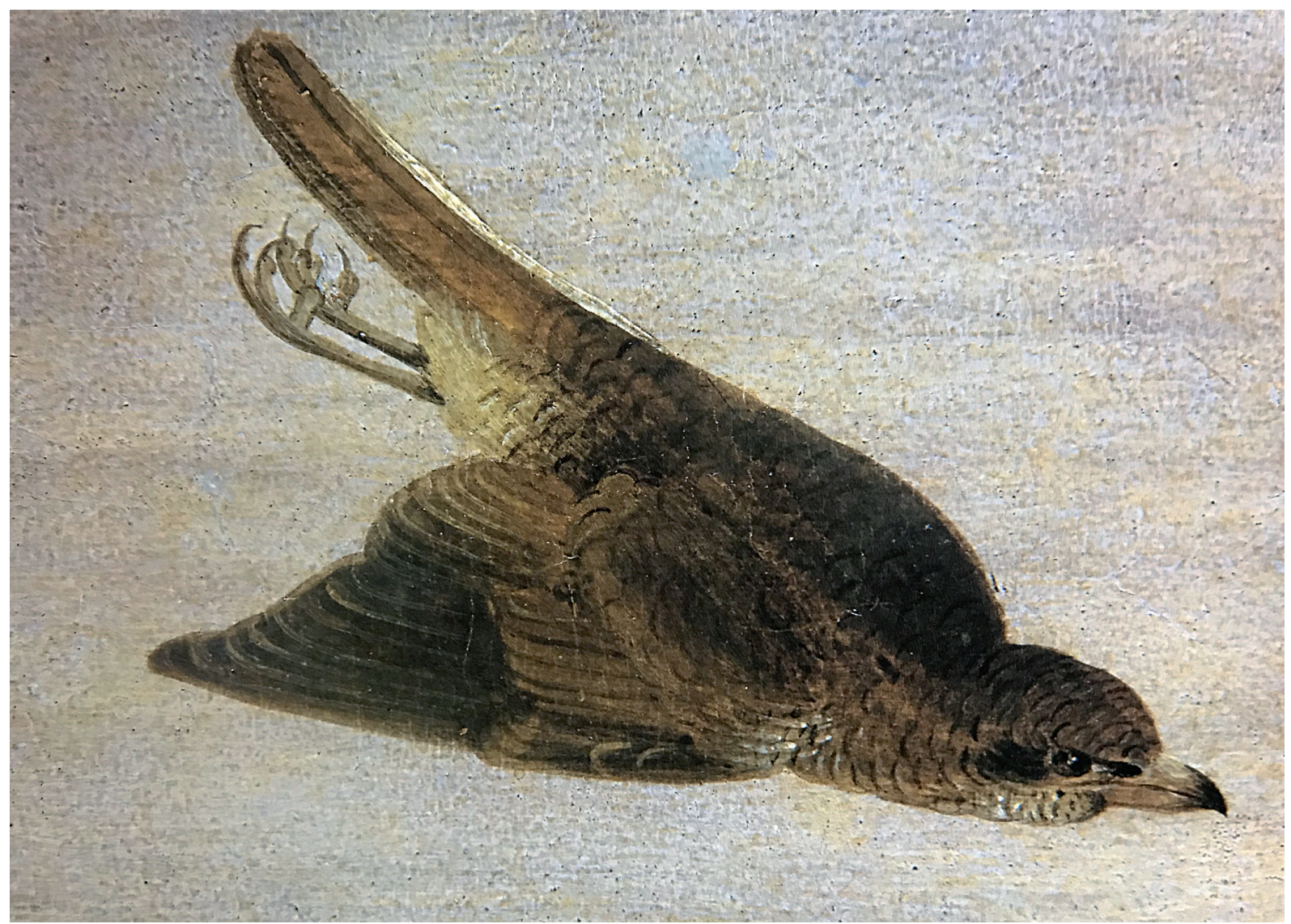

Fig. 2 - Detail of the Baptism of Christ. / Particolare del Battesimo di Cristo. (Courtesy Gallerie degli Uffizi, Firenze).

who love to catch doves"). I would like to point out that various species of falcons were used in falconry in the Late Middle Ages. Among them, we can mention the peregrine Falco peregrinus Tunstall 1771, the saker $F$. cherrug J.E. Gray 1834, the lanner F. biarmicus Temminck 1825, and the formidable gyrfalcon $F$. rusticolus L. 1758; but there were also smaller falcons which could be more appropriately called falconcelli, such as the merlin F. columbarius L. 1758, the hobby F.subbuteo L. 1758, and the kestrel F. tinnunculus L. 1758 (cf. Masseti, 2017).

There is, however, something very peculiar in the predatory behaviour of the red-backed shrike depicted in Verrocchio's Baptism of Christ, as in that of other shrikes such as the larger great grey shrike Lanius excubitor L. 1758, which differentiates them from raptors. As Antonioli Ferranti (2012) also observes, the red-backed shrike feeds on insects, small birds and even mammals. It is common knowledge for ornithologists and birdwatchers that the species (as several other shrike species) has the habit to spear its preys on thorns once killed, as Savi (1859) and Bacchi della Lega (1958) brilliantly described. The reason for this habit is to create a sort of larder with the killed prey, in order to return and feed on it when needed. Salvadori (1872) recounts having found a great number of crickets, beetles and cockroaches in some areas, impaled in such a way that there was no doubt it was the work of $L$. collurio, the only species of shrike he had seen in

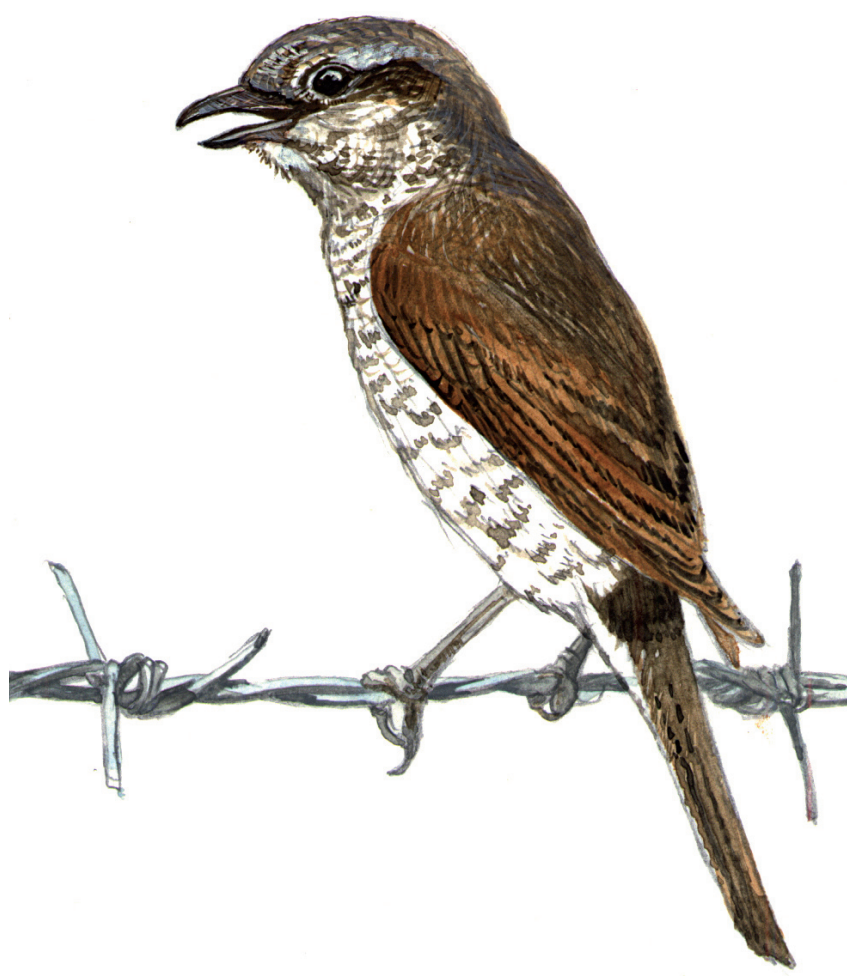

Fig. 3 - Portrait of a female of red-backed shrike, Lanius collurio. / Femmina adulta di averla piccola, Lanius collurio. (Drawing by: / Disegno di: Sandro Sacchetti). 
the area. Without going so far as to call into question the more complex Christian symbolism, the artistic evocation of a red-backed shrike in Verrocchio's Baptism of Christ reminds us of the thorns with which the head of Christ condemned to death was crowned, a condition not too dissimilar from the preys that the red-backed shrike spears in the brambles. Thus, the red-backed shrike could also have an undoubted meaning connected with the passion of Christ. Whether or why it flees at the appearance of the Holy Spirit in Verrocchio's Baptism of Christ is a question whose correct interpretation I prefer to leave to art historians, iconographers, theologians and semiologists. Why Verrocchio chooses to represent a female shrike and not a male is still a matter of speculation for which I cannot give an interpretation, but which surely has a symbolic reason. In fact, I believe that no detail in the composition of Renaissance artworks was due to chance.

\section{A SMALL RED-TAILED BIRD AMIDST PALM FRONDS}

It is also worth spending a few words about another bird image in the Baptism of Christ of Verrocchio. Above, but this time on the left-hand side of the painting, and slightly offset from the heads of the two angels, a dark silhouette darts through the palm fronds. The plant depiction illustrates the phenotypic characters of the date palm
Phoenix dactylifera L. (cf. Bircher, 1990), although in a heavily stylized version.

In the attempt to make the scene set in the unfamiliar Palestinian landscape more realistic, the artist enriched the painting with some exotic details, such as rare and unusual biological elements. In the case of the palm tree, however, he could not have been inspired by a living individual because this botanical genus was not to be found in $15^{\text {th }}$ century Tuscany. Thus, the manifest artistic stylisation of the plant suggests that its image was not depicted from life, but it was probably inspired by naturalistic repertories circulating in the workshops of the Florentine artists of the time (cf. Masseti, 2017).

For the record, the figure of the bird flying among the leaves of the palm tree had already been noted by Natali (1998b), which in any case defines it as: "[...] almost transparent and of poor workmanship" (Fig. 4). However, the artistic description of this bird is so careful that we can identify it without doubt as an adult male redstart Phoenicurus phoenicurus Gmelin 1789, a breeding and migratory bird species in Italy (Salvadori, 1872; Frugis, 1972; cf. Cramp, 1988) (Fig. 5). This is the first time this species has been identified among those depicted in the Baptism of Christ by Andrea del Verrocchio and Leonardo da Vinci, having been this detail overlooked by other commentators. Aristotle (Historia animalium, IX: 632 B 28) had already described its similarity to the European

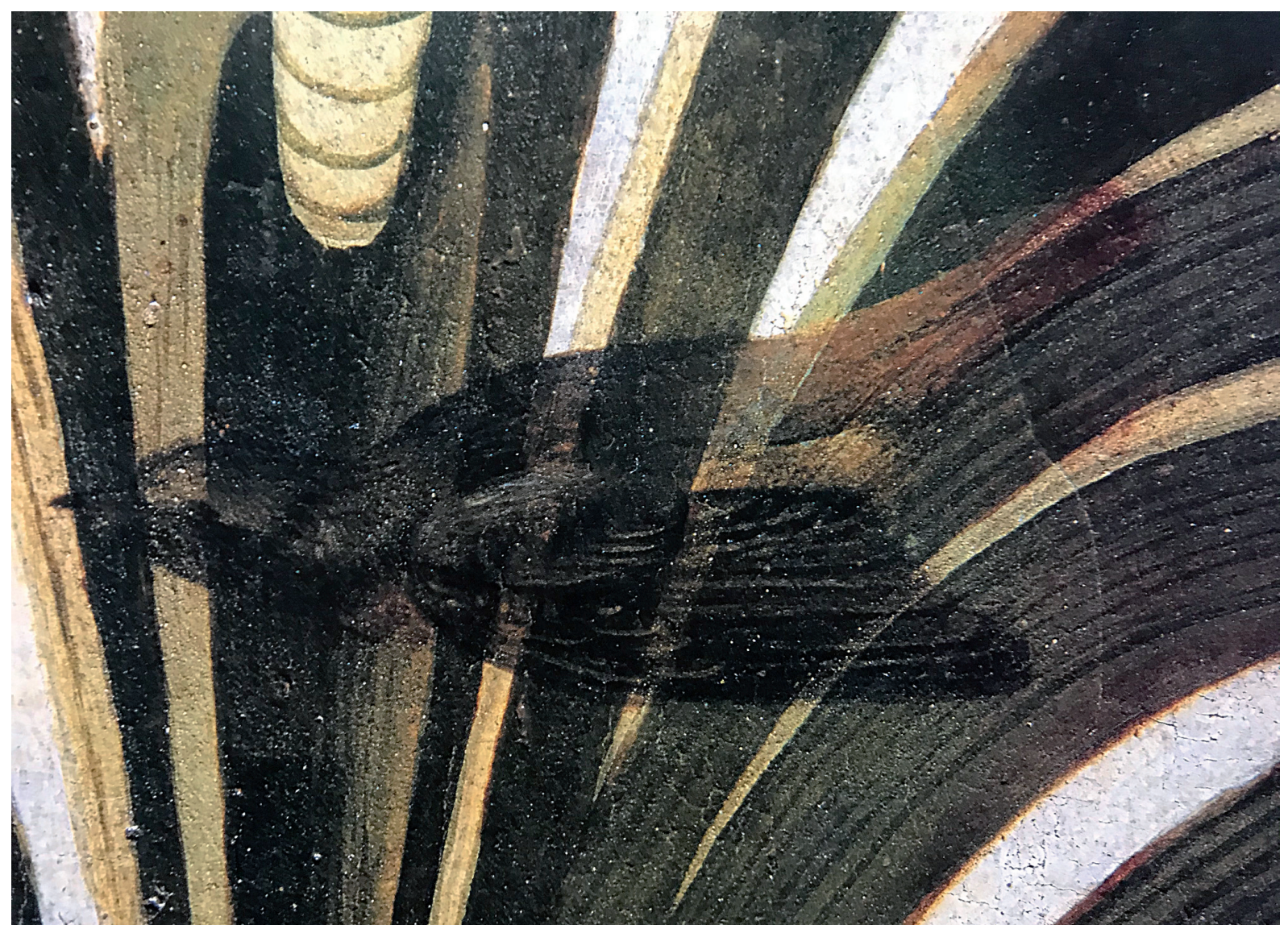

Fig. 4 - Male redstart Phoenicurus phoenicurus flying among the fronds of a palm tree, in another detail of Verrocchio's Baptism of Christ. / Maschio di codirosso Phoenicurus phoenicurus in volo fra le fronde di una palma, in un altro particolare del Battesimo di Cristo. (Courtesy Galleria degli Uffizi, Firenze). 
robin Erithacus rubetula (L. 1758), though in somewhat mystical terms (Pollard, 1977). It is possible that along with blue rock thrushes Monticola saxatilis L. 1766, redstarts were also kept as caged songbirds in Roman times (cf. Lamberton \& Rotroff, 1985). In the past, its captivity was particularly valued because, according to Olina (1622), it was a species that "Canta la Primavera come il Rusignolo" (= "Sings in spring like the nightingale").

The redstart is similar in length to the robin, but with a much more attenuated form, most obvious in the flatter crown, longer wings, and slim rump extending into a rather long tail. The latter is of a rufous-chestnut colour, always eye-catching whether flirted in flight or characteristically quivered when on the ground (Cramp, 1988). In the adult male redstart, as shown in the image evoked in Verrocchio's Baptism of Christ, the crown, back, and scapulars are blue-grey and the wings black-brown, but in the painting it is not possible to see the brilliant colour of the rump, because of the depiction of the bird in dorsal norm. However, the particularly striking red colouration of the tail could perhaps be assimilated to the peculiar plumage of other small songbirds, such as the already mentioned robin or the goldfinch Carduelis carduelis (L. 1758), whose image is traditionally adopted in contexts of Christological significance. Although neither of these birds is characterised by a red tail, other portions of their plumage are similarly coloured. According to Skinner (1925), the robin would fall into the latter category because, in the tradition, it pulled out a thorn from Christ's crown on the climb to Calvary and thus stained its breast with blood. Moreover, since every thorn and thorny bush alludes to the "crown of thorns" (Isidore of Seville, Etymologiae in Migne, 1844-1865, vol. 197 coll. 1117-1252), the goldfinch - carduelis in Latin, because it feeds on thistles (cardus) (see Masseti, 1980) - has also become a symbol of Christ's passion (Levi D'Ancona, 2000 and 2001). The bright red wing speculum can also be seen as a direct refe-

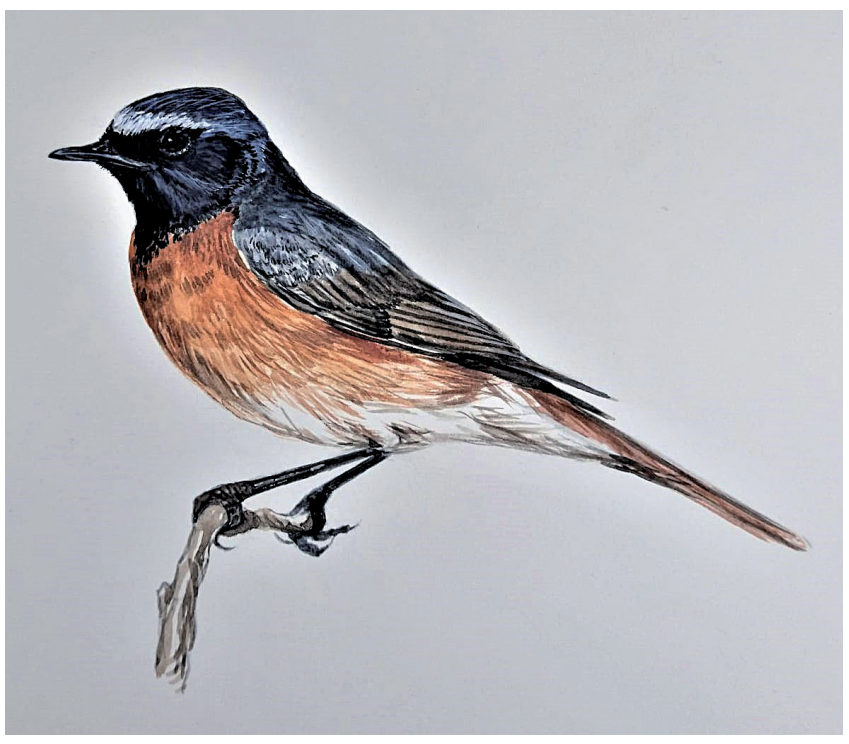

Fig. 5 - Portrait of an adult male redstart Phoenicurus phoenicurus. / Maschio adulto di codirosso Phoenicurus phoenicurus. (Drawing by: / Disegno di: Sandro Sacchetti). rence to the blood of Christ (Impelluso, 2003), as perhaps is the red chest of the robin or the vermilion tail of the redstart. It is precisely for this reason that the last bird may have been portrayed in the evocative context of the Baptism of Christ. Here too, however, I do not feel like venturing into further speculations on the symbolic meaning of the depiction of $P$. phoenicurus, which would take me far away from the naturalistic contextualization. The redstart is also a hunter, although more oriented towards the predation upon insects and other invertebrates, which it finds preferably in woodland, rocky hills, parkland and river banks with scattered old trees, orchards and gardens (Heinzel et al., 1998).

\section{DISCUSSION AND CONCLUSIONS}

The famous art historian Aby Warburg (1866-1929) has been credited with the phrase "God is in the details", which in turn he may have borrowed from Gustave Flaubert (1821-1880) (Titelman, 1996). This idiom expresses the idea that whatever is done, it should be done thoroughly i.e. the details are relevant. Concerning $15^{\text {th }}$ century Italian art in particular, as has been extensively discussed from Baxadall (1972) onwards, beyond the style of the pictures, it is rather important to focus on the relationship between these kinds of events and on how to read social history. This is done by examining the commercial customs, business contracts, letters and accounts of early Renaissance painting, and by explaining how the visual skills and habits that developed in the everyday life of this society influenced the style of its painters. This is why it can be important to investigate even the smallest - and apparently insignificant - detail of a painting, assuming that its presence in the artistic context is not the result of the painter's caprice but an expression of the precise will of the client, and the desire to express some precise symbolic meanings.

Returning then to the Baptism of Christ by Verrocchio and Leonardo da Vinci, and apart from the Holy Spirit, the other two birds evoked in flight in this painting are small-sized passerines, the redstart not exceeding $14 \mathrm{~cm}$, while the red-backed shrike is no longer than $18 \mathrm{~cm}(\mathrm{Pe}-$ terson et al., 1961; Heinzel et al., 1998). They are not exotic animals, but migratory birds that come to Italy during the warm season to breed and summer. The image of the shrike is undoubtedly derived from observing the animal in real life, but from a dead specimen. This is evident especially from the position the animal has been forced into, which is supposed to be motivated by the fact that the shrike is swooping down on a non-existent prey; or that, at least, has not been portrayed in the painting. Moreover, the bird's legs are not adhered to the body, as one would expect in such a posture, but as if they had been arranged in the best possible way to give the idea that the animal has been caught in a hunting situation. The portrait of the redstart also seems to be inspired by observation from life, perhaps of an individual that was in front of the painter's eyes at the time of its artistic evocation. However, it is not possible to establish with certainty whether the animal was dead or still alive at the time of its depiction, mainly due to the fact that it is 
partially covered by palm fronds. In any case, what can be seen is sufficient to appreciate the scientific rendering of the representation, undoubtedly allowing it to be attributed to an adult redstart male.

At this point, it may be worth noting that, of all the species of passerines that must have been living in Tuscany at the time, Verrocchio chose to portray these very two species of predatory birds in his Baptism of Christ. Moreover, there is no doubt that the painter has deliberately positioned one to the right and the other to the left of the Holy Spirit, while each is apparently heading in the opposite direction of the latter, at great speed. Here again, I cannot speculate on the potential symbolic meaning of the artist's choice, limiting myself to identify the bird species the painter wanted to represent. However, both birds are oversized in relation both to their spatial position in the perspective planes of the painting, and according to their actual size. Whereas in the case of the red-backed shrike we have no term of comparison regarding its position in the pictorial scene, it is evident that the size of the redstart - that flies among the palm fronds - should be much smaller than depicted, because it is positioned behind the group of human figures with which it should be in proportion. Art historians do not seem to give importance to such details, noting, for example in the case of Natali (1998b), that the bird portrayed "among the branches of the palm tree" is "almost transparent and of poor workmanship". On the contrary, we have clearly demonstrated that the artist gave a quite careful scientific representation of the characteristic morphology of an adult male P. phoenicurus.

\section{Acknowledgements}

In the course of this study, I have been fortunate to have the help of many friends and colleagues. I am particularly grateful to Giorgio Chiozzi (Museo di Storia Naturale di Milano), Giorgio Galletti (Università di Firenze), Antonio Natali (Firenze) and Muriel Vervat (Firenze).

\section{REFERENCES}

Antonioli Ferranti G., 2012 - Il rapace in fuga. Leonardo, Verrocchio e il Battesimo di Cristo. Edizioni Polistampa, Firenze.

Bacchi della Lega A., 1958 - Caccie e costumi degli uccelli silvani. Luciano Ferriani editore, Milano.

Baxandall M., 1972 - Painting and experience in $15^{\text {th }}$ century Italy. $O x$ ford University Press, Oxford.

Bircher W. H., 1990 - The date palm. A boon for mankind. Cairo University Herbarium, Faculty of Science, Giza (Cairo). Egyptian Studies Association, 2: 1-104.

BirdLife International, 2021 - Species factsheet: Lanius collurio. Downloaded 13/06/2021 from <http://www.birdlife.org>

Brichetti P. \& Fracasso G., 2011 - Ornitologia italiana, vol. 7. ParidaeCorvidae. Oasi Alberto Perdisa, Ozzano dell'Emilia (Bologna).

Caterini F. \& Ugolini L., 1938 - Dizionario dialettale italiano degli uccelli d'Italia. Edizioni Diana, Firenze.

Cramp S. (ed.), 1988 - Handbook of the birds of Europe, the Middle East and North Africa. The birds of the Western Palaearctic. Oxford University Press, Oxford/New York.

Frugis S. (ed.), 1972 - Enciclopedia degli uccelli d'Europa, II. Rizzoli editore, Milano.

Harris T. \& Franklin K., 2000 - Shrikes \& Bush-Shrikes: Including Wood-shrikes, Helmet-shrikes, Flycatcher-shrikes, Philentomas, Batises and Wattle-eyes. Princeton University Press, Princeton, and Christopher Helm/A. and C. Black, London.
Heinzel H., Fitter R. \& Parslow J., 1998 - Birds of Britain \& Europe with North Africa \& the Middle East. Harper Collins Publishers, London.

Impelluso L., 2003 - La natura e i suoi simboli. Piante, fiori e animali. Electa, Milano.

Lamberton R. D. \& Rotroff S. I., 1985 - Birds of the Athenian Agora. American School of Classical Studies at Athens, Princeton (New Jersey).

Levi D'Ancona M., 2000 - Il significato degli animali. In: Piante e animali intorno alla Porta del Paradiso. Levi D'Ancona M., Signorini M. A. \& Chiti Batelli A. (eds.). Maria Pacini Fazzi editore, Lucca: 71-74.

Levi D’Ancona M., 2001 - Lo zoo del Rinascimento. Il significato degli animali nella pittura italiana dal XIV al XVI secolo. Maria Pacini Fazzi editore, Lucca.

Masseti M., 1979 - Quando la religione viene in aiuto all'ornitologia. Le lingue del mondo, XLIV (8). Valmartina editore, Firenze: 517-518.

Masseti M., 1980 - Quando il cobra non uccideva. Le lingue del mondo, Valmartina editore, Firenze, XLV (2): 121-123.

Masseti M., 2001 - Lo studio dell'iconografia paleoambientale. In: AIN Atti del IX Congresso Nazionale "L'educazione ambientale nella cultura del cittadino europeo del 2000: idee a confronto". Napoli, 26-27 novembre 1998. Coppola L., Cabiati A. \& Maruccio L. (eds.). Associazione Italiana Naturalisti, Napoli: 45-53.

Masseti M., 2002 - Uomini e (non solo) topi. Gli animali domestici e la fauna antropocora. Firenze University Press/Università di Firenze, Firenze.

Masseti M., 2017 - Fiere esotiche e selvaggina nostrana. La raffigurazione zoologica nelle Adorazioni dei Magi fra il Tardo Gotico ed il primo Rinascimento italiani con particolare riferimento alle opere di Gentile da Fabriano e di Benozzo Gozzoli. In: La Luce Della Stella. I Re Magi fra arte e storia. Bedini A., Macchia G., Ognibene P., Panaino A. \& Piras A. (eds.). Mimesis Edizioni, Milano; Università degli Studi di Bologna, Bologna: 143-200.

Masseti M., in press - Strengths and limitations of artistic representations and literary descriptions of animals. In: Animals in Ancient and Medieval Cultures and Societies: Multidisciplinary Approaches. Zucker A., Vespa M. \& Franco C. (eds.). Studi e ricerche, Edizioni Università per Stranieri di Siena.

Migne J. P., 1844-1864 - Patrologiae Cursus Completus: sive Bibliotheca Universitatis. Petit-Montrouge, Paris: 224 voll.

Natali A., 1998a - Lo sguardo degli angeli. Tragitto indiziario per il Battesimo di Cristo di Verrocchio e Leonardo. Mitteilungen des Kunsthistorischen Institutes in Florenz, XLIL (2/3): 253-273.

Natali A., 1998b - Lo sguardo degli angeli. In: Lo sguardo degli angeli. Verrocchio, Leonardo e il "Battesimo di Cristo". Natali A. (ed.). Arti Grafiche Amilcare Pizzi, Cinisello Balsamo (Milano): 61-94.

Natali A., 2002 - Leonardo. Il giardino di delizie. Silvana Editoriale, Cinisello Balsamo (Milano).

Olina G. P., 1622 - Uccelliera ovvero Discorso della Natura e Proprietà di Diversi Uccelli. Andrea Fei, Roma (edited by F. Solinas, 2000. Leo S. Olschki, Firenze).

Peterson R., Mountfort G. \& Hollom P. A. D., 1961 - A field guide to the birds of Britain and Europe. Collins Publishers, London.

Picinelli F., 1681 - Mundus symbolicus. Garland Publications, New York and London (1976).

Pollard J., 1977 - Birds in Greek life and myth. Thames and Hudson, London.

Salvadori T., 1872 - Fauna d'Italia. Uccelli. F. Vallardi, Milano.

Savi P., 1859 - Ornitologia Toscana. Vol. I. Luciano Ferriani editore, Milano.

Skinner C. M., 1925 - Myths and legends of flowers, trees, fruits and plants. B. Lippincott, Philadelphia.

Tchernov E., 1984 - Commensal animals and human sedentism in the Middle East. In: Animals and Archaeology. Vol. 3. Early herders and their flocks. Grigson C. \& Clutton-Brock J. (eds.). BAR International Series, 202: 91-115.

Titelman G., 1996 - Random House Dictionary of Popular Proverbs and Sayings. Random House Reference, New York.

Yalden D. W. \& Albarella U., 2009 - The history of British birds. Oxford University Press, Oxford.

Zambon F., 1975 - Il Fisiologo. Adelphi edizioni, Milano. 